\title{
TRANSLATING THE RULES OF FOOTBALL IN SOUTH AMERICA, 1863-1914i
}

\author{
Traduzindo as Regras do Futebol na América do Sul, 1863-1914 \\ Traduciendo las reglas del fútbol en América del Sur, 1863-1914
}

\section{MATTHEW BROWN ${ }^{I^{*}}$}

DOl: http://dx.doi.org/10.1590/S2178-14942019000300002

\footnotetext{
i Acknowledgements: I am very grateful to Gloria Lanci, Bernardo Buarque de Hollanda, Martin da Cruz, Brenda Elsey and David Wood for their support and inspiration in researching this article.

I University of Bristol. Bristol, Reino Unido.

* Historian of Latin America. University of Bristol. (matthew.brown@bris.ac.uk) ORCID iD: http://orcid.org/0000-0002-2025-4433
}

Artigo recebido em 01 de julho de 2019 e aprovado para publicação em 28 de outubro de 2019. 


\begin{abstract}
This article explores the early history of Association Football in South America through the case study of the first translations of the rules of the game from English into Portuguese and Spanish. It demonstrates, by means of a comparison of the different temporalities and contexts of these documents, the connected and transnational nature of the sport. This has often been neglected in national paradigm studies of football pioneers and the first matches, clubs and leagues. The study of the translators suggests new avenues for the study of the interlinked histories of sport, politics and culture.
\end{abstract}

KEYWORDS: Football; Translation; Sport; Violence.

\title{
RESUMO
}

Este artigo explora o início da história da Association Football na América do Sul através do estudo de caso das primeiras traduções das regras do jogo do inglês para o português e o espanhol. Demonstra, por meio de uma comparação das diferentes temporalidades e contextos desses documentos, a natureza conectada e transnacional do esporte. Isso tem sido frequentemente negligenciado nos estudos nacionais de paradigmas de pioneiros do futebol e dos primeiros jogos, clubes e ligas. 0 estudo dos tradutores sugere novos caminhos para o estudo das histórias interligadas de esporte, política e cultura.

PALAVRAS-CHAVE: História; Futebol; Tradução; Esporte; Violência.

\section{RESUMEN}

Este artículo Este artículo explora la historia temprana de la Asociación de Fútbol en América del Sur a través de un estudio de caso de las primeras traducciones de las reglas del juego del inglés al portugués y español. Demuestra, comparando las diferentes temporalidades y contextos de estos documentos, la naturaleza conectada y transnacional del deporte. Esto a menudo se ha pasado por alto en los estudios nacionales de paradigmas pioneros del fútbol y los primeros juegos, clubes y ligas. El estudio de los traductores sugiere nuevas vías para estudiar historias interconectadas de deporte, política y cultura.

PALABRAS CLAVE: Historia; Fútbol; Traducción; Deporte; Violencia. 


\section{INTRODUCTION}

T here has been a remarkable expansion of new work on the history of sport in South America in general, and association football in particular, in the last decade (Melo, 2017; Brown, Elsey and Wood, 2018; Brown, 2015; Alabarces, 2018). Most of it has been carried out by scholars working in local newspapers and, more rarely, institutional archives, conducted by researchers inspired by the pioneers in the field. Its primary concerns with the history of this or that city, club or national league have tended to mean that it exists outside the field of global history. This article contends that the history of sport in South America should be an ideal case study to test some of the founding hypotheses of the discipline of global history. To what extent do global connections shape local processes? What is the role of mediators between cultures? At what point in the late nineteenth century do key transformations occur that shape the development of later globalizations? And at what stages and in what spheres does South America escape the role of periphery, or victim, that it is usually assigned in histories of globalization? This article suggests, by means of a case study of the first translations of the rules of association football in South America, that hybrid, vibrant and distinctive sporting cultures emerged shaped by both global pioneers and by the colonial past (following the insights of Dietschy, 2013, and Marquese and Pimenta, 2018). Translators were active mediators between cultures, shaping the past in ways that Anglophone historians of sport and politics have tended to be blind to until now (for example Bass, 2014).

Sports promoters in South America often wrestled with how to explain to the public exactly what it was they did, and why. When the "Football Association of Chile" (named in English rather than Spanish) announced in January 1898 that it would be holding its first Athletics "Championship Meeting" (using the English name for the event), it clarified: "el primer Championship Meeting, o sea, porque no tiene traducción posible en nuestro idioma, el torneo de diversos juegos atléticos establecidos por la asociación de football, según lo anunciamos hace algunos días" (there is no possible translation of Championship Meeting in our language - it means a tournament of diverse athletic games established by the Football Association) (El Mercurio de Valparaiso, 10 Jan. 1898). Sometimes just naming these sports was difficult enough. In its early days in 1899, the "Guayaquil de Sport" club advertised in the press that it had "spent this morning in our first exercise of the game of Bare-Ball, repeating it in the afternoon with a better result. On Sunday, members are invited to try the game of Cruket". Newspapers did not reveal how the members got on with either Bare-Ball or Cruket, and what similarity they might have had with baseball or cricket (El Grito del Pueblo, 23 Jan. 1900). 


\section{METHODOLOGY}

$\mathrm{T}$ he copying and adoption of these new practices would be good evidence for the phenomenon that is variously called "Eurocentrism", "cultural dependence" or "coloniality" in South America, which is to say a continued belief amongst previously colonized peoples that social practices emanating from the former metropolitan centres must, by their very nature and origin, be superior and worthy of emulation (Clevenger, 2017; Mangan, 2002; Buarque and Fontes, 2014). There is evidence for this attitude in other spheres of life, of course: in the words of one Colombian journalist, for example, "Europe is the centre of the greatest civilization the world has ever seen, and we cannot be indifferent to its current affairs, as we have received everything from there" (El Telegrama, 16 Oct. 1886).

The methodology of this article was to locate and analyse all of the translations of the rules of Association Football (FA) published in Spanish and Portuguese in South America between the codification of the rules in 1863 and 1914. Because most scholars of sport have not concerned themselves with the translators, the dataset is necessarily fragmentary and incomplete (for example, there is no information for Bolivia, Paraguay or Venezuela). I have supplemented work in secondary scholarship with primary evidence data-collection in archives across the continent. Before moving on to discuss these texts, I want to set up the comparative case of cricket, a sporting code which was already being played in many parts of South America before 1863, but which never achieved the level of popularity of symbolic meaning accrued by association football in the continent. The comparison with cricket sets up the analytical angle for study of the translators of football.

\section{THE UNTRANSLATABLE NATURE OF CRICKET}

ricket developed its codes and rules in the 1700s as part of the transformation of
English society, which Norbert Elias and Eric Dunning (1986: 167, 173) identified as representing "a profound sublimatory transformation of feeling" in which self-restraint was required and valued in order to "steadfastly renounce the use of violence" in politics as well as entertainment. What is now called "the spirit of the game" revolved around patience, respect for rules and delayed gratification - a code of conduct that was often spoken of as being more important than the game itself, and was adopted by imperial agents as inherent to the civilizing ethos of the British colonial project (Malcolm, 2012).While generally neglected from South American sports histories, cricket existed on the margins throughout our period, occasionally stepping into the spotlight. Cricket was played in Georgetown, the capital of 
Britain's only formal British possession in South America, in the mid-1800s, and Demerara (the team representing the colony of Guiana, today Guyana) played Barbados in first-class fixtures in 1865 (Beckles, 1998). Here, as elsewhere in Britain's Caribbean colonies, cricket was introduced as a strictly hierarchical form of separation and control, but adopted and eventually mastered by the local populations of black and Indian heritage. As C.L.R. James wrote in Beyond a Boundary, cricket was both a sport and a form of drama with an extraordinary representative capacity: "the long hours ... the measured ritualism and the varied and intensive physical activity which take place within it... leaves human personality on view" (1963: 194). In the late 1800s, Guyana was far from being the exception in South America. Stitching together references from a very fragmented set of sources we can see that cricket was being played in most seaports where British merchants were found. The sources suggest that it was cricket that set the foundations for football and its international, representative nature as it grew out of cricket clubs and grounds in the 1890s (for example, Chilian Times, 7 Jan. 1882; Magellan Times, 7 Jan. 1914). But there was little attempt to proselytize the game or found new clubs amongst the local population. It seems like cricketers did not necessarily trust that locally-born South Americans could behave according to the strict honour code of their game, or want to encourage them to do so.

Cricket, like cockfights, bullfights, and other forms of artistic practice in sport, were, to quote Clifford Geertz, (1972: 30) "not merely reflections of a pre-existing sensibility analogically represented; they are positive agents in the creation and maintenance of such a sensibility". The type of sporting practice that South Americans chose to practice was part of how they chose to represent themselves. The rules of Cricket were never translated to Spanish or Portuguese. Cricket was understood as a game that was too complicated and untranslatable, and also as a game that did not want to be understood by those it had not invited in.

An attempt was made by the newspaper Correio Paulistano, which provided an abbreviated guide in Portuguese in 1882 translating some of the terminology for "the curiosity of those who don't understand, so that they might attend a game and enjoy it". According to the author, who was clearly not a native speaker of English, two sticks were placed in the ground at each end of the pitch, joined with a small pole. The object of the game was "throw a ball so that it hits the sticks and makes the adversary's wicket fall down". The ball, it noted, was "as hard as iron". The bat was a "raqueta". The bowler was a "boller", suggesting that the translator was a Brazilian rather than a cricket native. Players should wear flannel clothing and protect their legs with "a type of shield, or leggings". The "match" was divided in two halves or "innings". When the ball is thrown at the "batter" they should use their "skill, 
strength and agility" to hit it as far away as possible. Yet, translations could only go so far. All parts of the game were said to be governed by "all manner of conventions" to be agreed by the players themselves, none of which were discussed or interpreted by the bemused Correio journalist (8 Sep. 1882).

\section{TRANSLATING FOOTBALL BEFORE 1900}

ost of the translations and annotated collections of rules were pamphlets sponsored
by local clubs or local associations. These institutions were the modern heirs to the exclusive city centre gentlemen's social clubs of mid-century, such as the Club de la Union in Guayaquil, the British Library in Buenos Aires, and the Club Americano in Bogotá, whose 1866 statutes stated that its aim was to "provide its members with recreations fit for a civilized society", and that the only games that were appropriate to this end were the likes of billiards, chess, dominoes, draughts, whist and other card-games (for Caracas, Venezuela, see the image of billiards in El Cojo llustrado, 1 Aug. 1901). These social clubs took up sports as an extension of their recreational activities, and also used them to promote their other activities within society. New sports meant rules and disciplines and physical vigour, as well as fun, gambling, and civilization like their old pursuits. Clubs sometimes published the rules of the game as an appendix to their statutes, which were handed to new members. But the statutes were mainly concerned with delineating who could or could not be a member, often prohibiting membership of more than one body simultaneously or clarifying personal characteristics around drink, income or clothing, more than they were with the sports themselves.

Histories of South American football have habitually ignored the first translators of the rules of the game, because of a fan's-eye preference for the simple idea that Association Football is a magically simple game which requires no tuition or guidance in order to play it. Yet, the difference between the lack of translated rules of cricket, which did not become popular in South America, and the multiplicity of published translations of the rules of Association Football, suggest that hard work and effort on the part of its promoters may have played an important role. The persistent translation and publication of the rules also suggests a sense that people were not playing the game properly, and that correctly interpreted, translated, and disseminated the rules of the game might be an aid to civilizing societies and the games they played in their free time (Elias and Dunning, 1986). In the next section I present the translations I have located, along with a preliminary analysis of their potential significance. ${ }^{1}$ 
In Buenos Aires, where we detected the earliest games of football, it is likely that rules and codes circulated orally, and through English versions brought and discussed by migrants. Thanks to the work of Victor Raffo and others, we know that most of the football played in Buenos Aires in the 1870s and 1880s was of the carrying variety we now associate with Rugby. No translations of the rules into Spanish have been located. In 1869, the Buenos Ayres Football Club simply noted 'the Committee has altered the rules to permit the carrying of the ball when it is caught before it touches the floor' (The Standard, 20 May 1868, in Raffo, 2005: 79). By 1874, football was being played in Buenos Aires according to rules "which differed from any existing code" and the Secretary of the Buenos Ayres Football Club urged "the adoption of one of two recognized sets of Laws now used in England in preference to continuing our own of last year" (The Weekly Standard, 13 May 1874, in Raffo, 2005: 153154). No written record of any changes made survives. It was only in 1903 that the Argentine Football Association published a translation of the rules, in its Guide to the Football Field. ${ }^{2}$

The first full translation of the rules of Association Football into Spanish or Portuguese comes not in one of the "major" South American footballing countries, but from Colombia. In 1892, a close translation of the 1863 Rules of Football was published in a newspaper in Bogotá, Colombia, by the United States military officer Henry Rowan Lemly. Already a published translator of military techniques and, later, of history, Lemly translated every term to Spanish, leaving no English words at all (El Telegrama, 23 Jun. 1892). He sought to render the game intelligible to his monolingual military students, as part of his mission to create a disciplined national corps of officers.

Regional histories of Colombian sport have competed to find the first football match in Atlantic port cities of Barranquilla and Santa Marta, in Cali and Pasto in the South, and in the capital Bogotá (Ruiz Patiño, 2010; Lopez Velez, 2010). In all of these places evidence has been found of cosmopolitan traders, elites who had been schooled in Europe, and one or two railway workers, reflecting some of the routes taken by football elsewhere in the continent. But Lemly's pioneer as a translator and military educator is revealing of the often underappreciated role of U.S sporting influence, and the agency of the military in sports promotion for national ends.

Lemly knew a fair bit about the conflict between so-called civilization and barbarism which so concerned sports promoters in South America before he arrived in Colombia. He served in the "Indian Wars", which extended the territorial reach of the United States in the 1870s, and he personally witnessed the surrender and murder of Lakota leader known as "Crazy Horse" in 1877, writing a widely-disseminated account of it in the New York Sun. 
A few years later he was in Colombia working at the newly-reestablished Escuela Militar, promoting gymnastics and physical exercise as a way of promoting a vigorous rigour amongst the country's officer corp. With the 1885-86 civil war bringing about a centralist Constitution and renewed attempts to foment a national identity, Lemly was in prime position to shape this national culture from the centre. Like many Colombian leaders involved in this project, Lemly thought that literacy was key to educating, civilizing, and Colombianizing a largely barbarian people. He translated the military tactics of Emory Upton, wrote about history and indigenous cultures, and studied translations. Unlike Miguel Antonio Caro, the president, grammarian, and translator, he persuaded to watch his first sporting experiments, he also believed fervently in a role for physical exercise and discipline in forging the nation (Arias-Escobar, 2017; Esquivel Triana, 2017; Deas, 1992; Polania, 2015). But Lemly did not leave the same legacy as football pioneers elsewhere. He returned to the U.S. and made only sporadic visits to Colombia after that, as a military advisor, arms trader, and historian (Lemly, 1884, 1891, 1901, 1910, 1923).

\section{HYBRID CODES AROUND 1900}

A sthe work of Tony Collins (2018) reminds us, there was no hegemonic footballing code Gaellic rules co-existed and interacted with pre-existing folk footballs and street ball-games. Historians have tended to focus their attention on digging up references to the versions of football that appeared most similar to the forms that later became hegemonic internationally. But when we allow ourselves to be guided by the surviving sources, we can see that football was played in many different ways, demonstrating the significant influence of individual mediators and translators, and their own personal experiences and preferences.

The example of the first translation of the Rules of Football in Ecuador provides us with some good insight here. The publication of these rules by Guayaquil's El Grito del Pueblo newspaper on three consecutive Sundays (28 Jan., 4 Feb., 11 Feb. 1900) is cited (though not reproduced) by all the serious studies of the origins of Association Football in the country. But it is clear from the beginning of the text, however, that this was not a close translation of Association Football rules like Lemly's in Colombia eight years earlier, but something else entirely - a hybrid sport drawing on Association, Rugby, and perhaps even the Eton Field Game. Rule 1 suggested that sides may have between 10 and 40 players each - though always divided equally. Rule 2 suggests "a big oval ball of $30 \mathrm{~cm}$ by $38 \mathrm{~cm}$ " which "must be extremely solid in order to resist the kicks that it receives". The translator adds the following advice on local ball-manufacture: "Ordinarily it is made from a rubber bladder enclosed in a 
tight sack or leather casing. The best are those which one makes oneself with a pig's bladder, which are stitched by a shoemaker with 'four pieces' of calf's leather strongly stitched, riveted with a hunting shoe, and finished in an opening with a small tie". In Rule 3, the translator notes that a rope should connect the two goal posts, but that "this is a complication which many serious players do not bother with, and they are happy to judge themselves whether the football has passed through at the appropriate height". Rule 5 notes that "the match will usually be made up of several 'chukkas' of three points each, in a period of time to be agreed beforehand". Rule 6 stated that "the 'football' should never be taken from an opponent with the hands, although it can be received, carried and deposited in the goal" . ${ }^{3}$ Rule 8 reveals a way of playing more familiar today as "touch rugby": "The aim of the game for each player is to make the ball pass behind the two posts of the opposing goal, or at least behind the line of the same name. To this end, all methods are valid, which is to say, it can be thrown there with a kick, or taken and carried towards the goal. On the other hand, the adversaries can chase the carrier, they can try to block his passage, to detain him, in a word, making it impossible for him to fulfil his design. But courtesy demands that the chase does not degenerate into pugilism, in body-to-body fights or bundles, as frequently occurs in countries of brutal and gross customs. The player who is waiting for the fugitive will be content, therefore, to touch the football shouting "Touched!". The intricacies of scrimmaging, or "forming a circle", were described at length. The game being "translated" here was a mixed-methods game combining elements of various kicking and carrying codes — not an outlier, but part of what Collins (2018: 88) calls "an international continuum of variations that stretched across the early football-playing world".

As the historians Navarro et al. relate (2014: 16), "in these years in Ecuador football was almost an extreme sport: there were no pitches, balls were made of wound-up rags, and the players used the game as an excuse to practice boxing. Their lack of basic understanding of football means that matches are decided throwing punches and rocks". With its oval ball, scrummaging and touchdowns it looks much more like Rugby Union Football. Some of its features, particularly relating to "touch", shows strong affinities with the Eton Field Game (Eton College, 2007). Discomfort with the physicality of rugby, and its potential to precipitate fights or hand-to-hand combat "as frequently occurs in countries of brutal and gross customs", perhaps explains the preference for the "touch" tackling system used at Eton College. The division of the match into three "chicos" or chukkas is akin to polo, not association football, which has never experimented with more than one interval. It seems that the author/translator produced this document from memory, perhaps even fusing elements of games they had played or heard or read about. The most likely author is Juan Alfredo 
Wright, a Guayaquil merchant and grandson of one of Bolívar's admirals. He was born in Guayaquil on 24 July 1882, and received his secondary education at the Colegio Vicente Rocafuerte. He studied in Lima, where he is reputed to have encountered football for the first time by joining the Club Union Cricket. He returned to Guayaquil from Callao in August 1899, bringing "the first football to Ecuador" (Roque Salcedo, 1947: 1; Navarro et al., 2014: 15). He does not appear on the Eton College Registers, and I have not been able to find out yet where he went to school. Allowing for some inaccuracies in the dating of his education presented in his biographies, it is not inconceivable that he returned from a spell at a British school in 1899 or 1900 and published the rules of a game he played at school. The version of football translated, published, and played in Guayaquil in 1900 was a hybrid form, a mixture of the codes of association, rugby, and private school football still circulating and competing with each other in this period (Kitching, 2015). This example demonstrates very clearly the global dimensions of those competing codes, rather than, as has often been presumed in the historiography, a model in which Association Football became the dominant code and then asserted its hegemony in the British informal empire in South America.

\section{INCREASING COMMONALITIES}

T he first translations of the rules of football in the River Plate appear to have been undertaken from around 1898, at the stage where the sport was first being deliberately popularised beyond the English-speaking communities. The years around 1898-1900 saw a peak of translations of the English FA's rules, all apparently conducted independently without mutual reference. First, the Reglas del Juego de Football were published by Albion Football Club in Montevideo in 1898. ${ }^{4}$ The most likely translator of the Rules in Uruguay was Bristol-born Henry Castle Ayre. ${ }^{5}$ An English teacher at the English High School in Montevideo, Henry Castle Ayre was already a published translator of historical works, and developed his own "Ayre Method" for learning English as a foreign language. He followed the FA rules very closely, without annotations or commentary, providing English originals in italics and brackets after the first mention of new words, for example "puntapie de esquina (corner kick)". His innovation was the use of "valle" to describe the goal-area and its extension "guarda valle" as goal-keeper. In Peru, the Rules of Football appear to have been first published in Spanish in El Sport (7 Aug. 1899, cited in Muñoz, 2001: 229), with the commentary that "football produced freedom-loving men, respectful of authority and law, self-sufficient and full of the spirit of association". In 1901, the first translation of the Rules of Football into Chilean Spanish appear to have been made by J.D. Sieveking, in an edition prologued by the magistrate José Alfonso in 1901 (who in 1903 
became president of the first Football Association of Santiago). Alfonso particularly valued the "strict discipline, constant vigilance and strategy" required by the game (cited in Modiano, 1997: 82, also discussed in Santa Cruz, 1996). Chilean commentators constantly admired the use of "an iron hand" to maintain "the strictest discipline" in matches (El Sportsman, 19 May 1907, in Modiano, 1997: 96).

It was at this point that the translations started to dedicate more time and space to explaining football's laws around violent conduct (particularly laws nine and ten, which were amended by the International Football Association Board - IFAB — in this period). IFAB was a committee with representation of the English, Welsh, Irish, and Scottish associations, and thereby reflected the dominance of the English language on the rules of football, as yet unchallenged by the rise of FIFA (Fédération Internationale de Football Association) in the first decade of the new century. The translations both coincide with and were designed for the growing popularization of the game, and were intended both to keep the versions played locally in line with international norms as imagined in Great Britain, and to control workingclass, migrant, and non-white footballers, and the violence it was feared they would bring into the game. The Argentine Football Association in 1903 (34-5) ran the Spanish and English versions in parallel columns on the same page to make it plainer how close the translation was to the original, especially useful for its bilingual members.

The Guides to sports published in South America at the beginning of the twentiethcentury were principally concerned with promoting participation than in fighting linguistic battles. The Guides were hybrid texts, explaining where, how, and why to play sports properly, and certainly not simple translations of a British model. As they took with the language of sports, translators attempted to preserve the cultural ethos which they inferred to be inherent in the games. A good example is the Guia de Football produced in São Paulo, Brazil, by Mario Cardim and Luiz Fonseca in 1906 (in Gambeta, 2014: 49-181). The book included the Statutes of the Sao Paulo Football League, the rules of Association Football and guidance for referees, a discussion of the "physical and moral qualities of the footballer", fixtures and records of the São Paulo Football League, including details on each club and on tram timetables to enable the public's attendance at matches, statistics, and information for the Brazilian National Football Championship and schools football. It featured photographs of key players and discussion of their playing style. The approach to the language of sport was creative and littered with English and French words. Cardim and Fonseca kept many English-terms in their text, such as teams, forwards, match, goal, corner-kick, throw-in, incorporating their own translations and explanations into the text on first mention, as in their translation of the second law of 
the game, "Feito um goal, o lado que perdeu tem direito ao ponta-pe inicial (kick-off)". Their text featured many original terms alongside translations, as is illustrated by their annotated map of the pitch, the Campo de Football. This was a hybrid text like many others. Cardim and Fonseca probably drew on the work of their colleague Hans Nobiling, the founder of S.C. Germania, who brought German copies of the statutes of the Hamburg Football League with him to Brazil, and was a prime mover in the organization of the Paulista League (Gambeta, 2014: 39). They also drew on the work of the French author Ernest Weber (1907), which was reprinted several times in Rio de Janeiro in those years. Although the identity of the translator or translators into Portuguese are not known, this does further weaken the claim of England and English as the common origin point of South American Association Football. (Belford Duarte, who played for Mackenzie College, is sometimes held to have translated the rules to from English to Portuguese in 1902, as in Enciclopédia, 2001:35.) The Guia de Football was heavily littered with English phrases, with a lot of attention focused on explaining the degree of physical violence that was allowed, hence the phrasing that "Nao e permittido a nehum jogador passer rap-ponta-pe, teira, dar ponta-pes ou pular sobre o adversario. [...] A charge e permittido mas nao de um modo violento ou perigoso. Nenhum jogador pode empurrar um adversario pelas costas salvo quando este estiver empedindo um adversario" (charging is permitted but not in a violent or dangerous way) (in Gambeta, 2014, 39-40).

Sometimes the translators brought a new word directly into the Portuguese, which is the case with dribbling, which became and remained a Portuguese verb, driblar. This came from the French - the dribleur is noted to be renowned for their trucs or tricks. Yet, the translation of the rules and the explanation of the game were explicitly locally- as well as globally-situated. In their discussion of goalkeepers (2014: 106), Cardim and Fonseca note that "Cruisbank", the Fluminense goal-keeper of 1902-04, "revolutionized the defending of our goal-keepers" through his innovative handling, and that "today there are two goal-keepers who live up to this standard in São Paulo — Thompson of SC Internacional and Satler of Mackenzie College". As the diagrams of the playing field reproduced in many of these texts clearly show, the translation of sports terms became an issue of naming and identifying new spaces. The pitch itself was a political, as well as a geographical space.

\section{INDIGENOUS FOOTBALL}

$\mathrm{T}$ here was no hegemonic football code in South America in the first decades of the 1900s, as a myopic focus on Buenos Aires and the triumphs of Alumni and its British pioneers might have us believe. As the examples discussed above have shown, individual promoters, 
translators, and mediators created distinct sporting cultures in many different spaces. In Chile we find perhaps the most creative translation of the Rules of Association Football, dating from 1914 when Manuel Manquilef published the rules of the Mapuche sport of "Trümen". Rather than adopting the British sport and preaching its values to his peers, Manquilef used it to legitimize the indigenous sporting cultures of his ancestors with a broad spectrum of cultural comparators. He translated trümen into Spanish as "El foot-ball". In his publication, part of an extensive study of Mapuche sports and pastimes, Maniquilet published a version of the rules of football in Mapudungun down the left side of his page, and Spanish on the right. It describes four-a-side football, and shows significant continuity with other Mapuche sports in its scoring system. It includes a kind of scrimmaging but with no hands. A point was scored by getting the ball over the end of the pitch. Here is my English translation of Manquilef's seven rules:

1. This game is very ancient and powerfully develops physical strengths.

2. Trumen is similar to foot-ball, differing only in the number of players which, instead of eleven, are four per side.

3. The ball is a large oval of dried grasses wrapped in a very resistant leather. The ball also used to be made of thread and leather.

4. Two sides are formed with four players each. The referee gives the signal to begin, and the Indian carries the ball with their feet. It is a foul if they use their hands.

5. When the ball is controlled by the feet, a terrible struggle around it is mounted, and the strongest leave their opponents on the ground. They go on to reach the gate (puerta), which is the signal for the end of the field.

6. The side which scores four times in a row is considered to be the winner. Until then, the losing side can continue to reduce the deficit or reach a draw.

7. For example, if one side scores 3 and the other 1, the winning side is leading by two scores. In this way, the game can be very entertaining and can continue for a long time. The game of trumun is also known as the tropezon, the bundle, because of the falls to which the Indian is subjected (1914: 76, 125).

By his repeated use of Foot-Ball in Spanish/English to name and reference the game, Manquilef was arguing for its similarity with and equivalence to football. But he is also, less obviously, translating Association Football into towards an approximation of a Mapuche sport. He is making claims in both directions, that Trümen is like football, and also that football is like Trümen. His reference to an oval ball, and the references to bundling and scoring by reaching the end of the field show far more similarities to the carrying codes than to Association Football. 
Manquilef's publication formed part of a wider continental wave of translations around 1910-13, and all of these sought to explain and control the "problem" of rough play, which was a legacy of the carrying-codes such as Rugby. Some translators and promoters looked to minimise physical contact, whereas others sought to limit, explain and harness it. A Chilean Physical Education teacher working in the capital's Instituto Nacional, Guillermo Martinez, translated the updated Rules of Football in 1910, published by the Centro Editorial de Sport. He proclaimed his version to be "a faithful translation of the Rules of Football of the English Association' making them the 'last word in the question of the rules of the beautiful game of foot-ball which the youth of our country have embraced with such enthusiasm'". Martinez (1910: 1-5) saw his translation as an act of accommodation between cultures. "We have managed to adapt the English expressions and phrases to Chilean language, by means of conserving those which have entered into general use and acceptance, and which already form part of our daily vocabulary". Martinez lamented that in 1906 the Diener publishing house had produced a translation of the rules in which "the lack of command of the Chilean language was obvious" (I have not been able to locate a copy of this translation). "We believe that our sportsmen who play foot-ball will understand and appreciate the effort that we have made to explain in accessible language the rigorous, laconic and sometimes confusing intricacies of the English Football Association's rules of the game. Nevertheless, these rules govern foot-ball all around the world and more than 10 million people play the game according to its regulations". Each rule was supplemented with guidance for referees, for linesmen, for club secretaries, and for players, often extending to several pages and making reference back to the findings of the IFAB. Martinez may also have been the author of the 1912 text, cited in Modiano (1997: 37), with its admonition that "football is a violent game, and therefore players should avoid any intentionally brutal action". In 1913, the newspaper La Cachimba Sportiva aimed to further disseminate the rules of the sport, and knowledge of correct sporting conduct, amongst the working population, and may have published further translations (Modiano, 1997: note 197).

\section{TOWARDS HOMOGENIZATION AFTER 1910}

【 $\mathrm{n}$ Ecuador, in 1912, the English FA regulations were published for the first time (Reglamento, 1912). The unnamed translator provided the English original of all terms in brackets after his translation, as in Rule 2 " Los ganadores de la rifada ('toss') tienen derecho de elegir lado o dar el primer puntapié ('kick-off')", indicating their perception that readers would not necessarily be familiar with the original version. The pamphlet featured an "Explanation of Terms", which clarified the meaning of Place Kick, Free Kick, Carrying, Knocking on, Handling, 
Tripping, Holding and Touch. These specialist translations, which sought to make intelligible the English Football Association Rules, and to guide footballers in their correct observance, were not the only translations being made. These translations, and the accompanying comments, demonstrate clearly the process of regulating and limiting the more physical carrying game that was first played in South America.

The eventual printing of the rules of Association Football in Ecuador 1912 was the catalyst to the formation of leagues and competitions, which had not been instituted beforehand because of a lack of common regulations. By retaining English terminology, the translator hoped to retain the privileged position of the English language within a way of thinking about football, whilst making it as accessible as possible — within that limitation — to non- English speakers. This was a large step away from the translator of the 1900 rules, who had produced a hybrid text, full of commentary and intervention, on top of a hybrid set of rules. In 1912, a match took place between teams from Guayaquil and Quito using the newly-translated rules. The referee was George Jatton, an "employee of the railway company" and presumably the same "Hatton" remembered by some oral histories of early football of Quito. This makes him a good candidate to be the translator (Baquerizo and Carrera, 2012: 22; La Hora, 2000). Another alternative would be Consul Alfred Cartwright, who had an increasingly visible role in the promotion of sport in Guayaquil post-1912, as one of the sponsors of the Asociación de Empleados which took a lead in organising competitive sports in Ecuador (Roque Salcedo, 1947: 6; El Telegrama, 7 Nov. 1912).

The role of South American sporting administrators in civilizing football was only partially picked up by outsiders at the time. What later became admiration at rhythm, technique, and athleticism was initially perceived as a lack of "ruggedness" or propensity for rough play. Elmer Mitchell's influential 1922 work "Racial Traits in Athletics" stated that "the South American athlete has not the physique, environment or disposition which makes for the champion athlete". But what Mitchell and others failed to note was that South American teachers, translators, and players were promoting versions of sports, particularly football, that limited physical violence on the playing field. They were consciously "civilizing" the game for their own ends. The number of independent national translations published between 1910 and 1912 (for example Reglas, 1910; Oliveira, 1912; Manquilef, 1912, Reglamento, 1912) responds to the coming together of a shared continental trajectory as the games' international framework began to coalesce around FIFA. 


\section{CONCLUSIONS}

he abundance of translations of the rules of football codes in South America before
1914 demonstrates the rich variety of sporting cultures that emerged in the continent before the formation of CONMEBOL (Confederación Sudamericana de Fútbol) in 1916, and the subsequent gradual efforts of FIFA to homogenise the game to facilitate international competition. While we have identified many international sporting networks here, testament to the global history approach adopted, it is important to recognize limits. There is not much evidence of transnational connections within South America in this area. Separate surviving independent translations from English language originals have been located in Argentina, Uruguay, Colombia, Chile, Ecuador, and Brazil, and it seems likely that others exist too. The translators included British pioneers as we might expect, such as Henry Castle Ayre in Uruguay, but this influential group was much more diverse than that, including a North American (Henry Rowan Lemly in Colombia), and migrants of German background (Nobiling and Sieveking), and native Spanish and Portuguese speakers (Cardim, Fonseca, Martinez). The Ecuadorian case is suggestive (but nothing more) of links along the Pacific coast. Various cities, regions, and states adopted and adapted the game according to their own pre-existing sporting and political cultures. As the case of Manquilef in Chile shows, the processes of translation and mediation studied here went beyond English, Spanish, and Portuguese.

The primacy of English in association football was subject to all sorts of influences and pressures. By the time of the first FIFA World Cup, held in Uruguay in 1930, the organizers recognized the existence of multiple understandings of the rules of Association Football, as a result of these diverse trajectories from an original football that had itself encompassed competing versions of how much the ball could be carried, and how often and in what ways the opponent could be manhandled. The tournament regulations in 1930 stated that the rules of the International Board would be used, and that if there was any doubt over their interpretation, the English language version would be definitive (in Carbonnell, 1931: 16). Before it started, the Organizing Committee took the trouble of passing a resolution on "Good Play" (Buen Juego): "It was resolved to pass a note to the World Cup referees, so that they are aware that on the field of play, they should ensure the faithful adherence to the rules of the game, in order to avoid any potential dangers to the physical integrity of the players". Here, after thirty years of working to limit physical violence on their respective pitches at home, the South American organizers made this their final word to the representatives of the laws of the game (in Carbonnell, 1931: 20). 
We still know far too little about the role of referees in shaping football cultures in the early years of the sport. Historians have preferred to investigate players, fans, and playing spaces in their search for the origins of the traditions and identities that continue to shape our lives in the twenty-first century. This article has sought to bring the role of translators out of the darkness and into the global history of football and its social significance. The next step will be to investigate the reception of those sporting rules, through the history of referees and the always incomplete implementation of the law. Referees had to interpret the laws of the game, and in order to do that, the interpreters relied on the hidden labour of the translators.

\section{NOTES}

1 Of course this argument is based on just the surviving fragment of the contemporary source material. I do not doubt that very many more translations of the rules of soccer survive in club libraries and private collections that I have not accessed, and I hope that this article serves to bring others to light. I am grateful to the reviewers of this article for bringing further potential sources to my attention,

2 Held in the Sergio Lodise Collection in Buenos Aires, kindly shared with me by Chris Bolsmann.

3 This is an ambiguous translation - use of terms rester for to take, literally to "wrest"; tomar also to take, translated here as "received".

4 I am very grateful to Martin Da Cruz for sharing this document with me.

5 Henry Castle Ayre, born in Bedminster, Bristol, in the first quarter of 1852. Somerset births ref: 5C/768. In the 1871 UK Census he was living in Denmark Place, Horfield, Clifton, Bristol, with his brothers and sisters.

\section{BIBLIOGRAPHY}

\section{NEWSPAPER CONSULTED}

Correio Paulistano, São Paulo, 1882.

El Cojo llustrado, Caracas, 1901.

El Grito del Pueblo, Guayaquil, Ecuador, 1900.

El Mercurio de Valparaiso, Valparaiso, Chile, 1900.

El Sport, Lima, Peru, 1899.

El Sportman, Santiago, Chile, 1907.

El Telegrama, Bogotá, Colombia, 1886, 1892.

El Telegrafo, Quito, Ecuador, 1912. 
Magellan Times, Punta Arenas, 1914.

The Standard, Buenos Aires, 1868.

The Weekly Standard, Buenos Aires, 1874.

\section{ARTICLES AND BOOKS}

AFA. Guide to the Football Field. Buenos Aires: AFA, Sergio Lodise Collection, Buenos Aires, 1903.

ALABARCES, Pablo. Historia mínima del fútbol en América Latina. México D.F.: Colegio de México, 2018.

ALBION FOOTBALL CLUB. (1898) Reglas del Juego de Football, aceptadas en la Conferencia Internacional, traducción aprobada por el Albion Football Club, Montevideo. Montevideo: Al Libro Ines, 1898.

ARIAS-ESCOBAR, Felipe. Bogotá 1892: ¿125 años de fútbol en Colombia?ln: La Monserga del Fútbol (site). Disponível em: <http://www.lamonsergadelfutbol.com/?p=6865>. Acesso em:2 Out 2017.

BAQUERIZO, Maldonado; CARRERA DROUET, Virgilio. Historia del movimiento olímpico. Quito: COE, 2012.

BASS, Amy. State of the Field: Sports History and the "Cultural Turn", Journal of American History, v. 101, n. 1, 2014, p. 148-72.

BECKLES, Hilary McD. The Development of West Indies Cricket: Vol. 1 The Age of Nationalism. Kingston: University of the West Indies Press, 1998.

BROWN, Matthew; ELSEY, Brenda; WOOD, David. Football History in Latin America. Bulletin of Latin American Research, v. 37, n. 5, 2018, p. 537-8.

BROWN, Matthew. British informal empire and the origins of association football in Latin America, Soccer and Society, v. 16, n. 2-3, 2015, p. 169-182.

BUARQUE DE HOLLANDA, Bernardo; FONTES, Paulo (orgs). The Country of Football: Politics, Popular Culture and the Beautiful Game in Brazil. London: Hurst \& Co, 2014.

CARBONNEL DEBALI, Arturo (org). Album: Primer Campeonato mundial de football. Montevideo: Ediciones de Impresora Uruguaya SA, 1931, reprinted 2000.

CARDIM, Mario; FONSECA, Luiz. Guia de Football. São Paulo, 1906.

Chilian Times, Valparaiso, 1882.

CLEVENGER, Samuel M. Sport history, modernity and the logic of coloniality: a case for decoloniality, Rethinking History, v. 21, n. 4, 2017, p. 586-605.

COLLINS, Tony. How Football Began: A Global History of How the World's Football Codes Were Born. London: Routledge, 2018.

DEAS, Malcolm. Miguel Antonio Caro and Friends: Grammar and Power in Colombia, History Workshop Journal, v. 34, n. 1, 1992, p. 47-71.

DIETSCHY, Paul. Making Football Global? FIFA, Europe and the non-European Football World, 1912-1974, Journal of Global History, v. 8, n. 2, 2013, p. 279-98. 
ELIAS, Norbert; DUNNING, Eric. Quest for Excitement: Sport and Leisure in the Civilizing Process. London: Wiley-Blackwell, 1986.

LA HORA. El Ejido, escenario insólito. La Hora (Quito), 5 Fev. 2000. Disponível em: <http://www.lahora.com. ec/index.php/noticias/show/1000011337/1/El_Ejido,_escenario_ins\%C3\%B3lito.html\#.VSupq_nF98E>. Acesso em: 3 de jul. 2019.

LANCE. Enciclopédia do Futebol Brasileiro, Volume 1. Rio de Janeiro: Aretê Editorial, 2001.

ESQUIVEL TRIANA, Ricardo. Influencia liberal estadounidense en el ejército colombiano 1880-1904, Revista Científica General José María Córdova, v. 15, n. 20, 2017, p. 227-46.

ETON COLLEGE. Field Games Laws. Eton: Eton College, 2007.

GAMBETA, Wilson. Os primeiros passos: Documentos para a história do futebol em São Paulo (1897-1916). São Paulo: LUDENS, 2014.

GEERTZ, Clifford. Deep play: Notes on the Balinese cockfight, Daedelus, v. 101, n. 1, 1972, p. 1-37.

JAMES, C.L.R. Beyond a Boundary. London: Hutchinson, 1963.

KITCHING, Gavin. The Origins of Football: History, Ideology and the Making of 'The People's Game, History Workshop Journal, v. 79, n. 1, 2015, p. 127-53.

La Cachimba Sportiva, Santiago de Chile, 1913.

LEMLY, Henry Rowan. Ejercicios gimnásticos. New York: D Appleton y Cia, 1884.

LEMLY, Henry Rowan. Reglamento de la Escuela Militar. Bogotá: Escuela Militar, 1891.

LEMLY, Henry Rowan. Táctica de infantería, adaptada a la topografía Sudamericana y a los rifles ultima invención. New York: D Appleton y Compañía, 1901.

LEMLY, Henry Rowan. Táctica de infantería ... traducida y arreglada a las necesidades del ejército de Colombia por HR Lemly .... tercera edición, revisada, by Emory.

LEMLY, Henry Rowan. A grammar of the modern Spanish language. Boston: Ginn and Co, 1910.

LEMLY, Henry Rowan. Bolívar, Liberator of Venezuela, Colombia, Ecuador Peru and Bolivia. Boston MA: Straford, 1923.

LOPEZ VELEZ, Luciano. Detrás del balón: Historia del futbol en Medellín 1910-1952. Medellín: La Carreta Editores, 2010.

MALCOLM, Dominic. Globalizing Cricket: Englishness, Empire and Identity. London: Bloomsbury, 2012.

MANGAN, J.A. The early evolution of modern sport in South America: A mainly English Middle-Class Inspiration? In: MANGAN; DACOSTA, Lamartine P. (orgs)., Sport in Latin American Society: Past and Present, London: Frank Cass, 2002, p. 9-42.

MANQUILEF, Manuel. Comentarios del Pueblo Araucano: II La Jimnasia Nacional (Juegos, Ejercicios y Bailes). Santiago: Annales de la Universidad, 1914. 
MARQUESE, Rafael; PIMENTA, João Paulo Garrido. Latin America and the Caribbean:

Traditions of Global History. In: BECKERT, Sven; Sachsenmaier, Dominic (orgs). Global History, Globally: Research and Practice Around the World. London: Bloomsbury, 2018.

MARTINEZ, P. Reglas de Foot-Ball. Santiago: Imprenta Lourdes, 1910.

MELO, Victor Andrade de. History of Sport in Brazil and in South America: Visibility for New Looks, International Journal of the History of Sport, v. 34, n. 5-6, 2017, p. 399-404.

MITCHELL, Elmer D. Racial Traits in Athletics, American Physical Education Review, 1922.

MODIANO, Pilar. Historia del deporte chileno: Orígenes y transformaciones, 1850-1950. Santiago: DIGEDER, 1997.

MUNOZ CABREJO, Fanni. Diversiones públicas en Lima: 1890-1920: La experiencia de la modernidad. Lima: PUCP, 2001.

NAVARRO GUZMAN, José; LEAL AYALA, Alfonso; GRANJA TERAN, Patricio; NARANJO RODRIGUEZ, Jaime; LASAO AYALA, Julio. El fútbol que más nos gusta: la historia del Campeonato ecuatoriano, 1899-2013. Quito: La Red Editores, 2014.

OLIVEIRA, O. T. de. Guia de Football (Association). Pelotas: Officinas da Livraria Universal, 1912.

POLANIA, Daniel. Cinco teorías sobre cómo llegó el fútbol a Colombia. (site) In: Danielpolania's Blog (site). Disponível em: <https://danielpolania.wordpress.com/2015/03/26/cinco-teorias-sobre-como-llego-el-futbol-a-colombia/> Acesso em: 26 Mar. 2015.

RAFFO, Victor. El origen británico del deporte argentino: Atletismo, cricket, fútbol, polo, remo y rugby durante las presidencias de Bartolomé Mitre, Domingo Sarmiento y Nicolas Avellaneda. Buenos Aires, 2005.

Reglamento del Club Americano. Bogotá: Club Americano, 1866. Biblioteca Nacional de Colombia, Fondo Pineda.

Reglamento del Juego Foot-Ball. Quito: Encuadernación La Juventud, 1912.

ROQUE SALCEDO, Miguel. Apuntes para la historia del fútbol en el Ecuador: Guayaquil, cuna del fútbol. Guayaquil, 1947.

RUIZ, Alejandro B. UPTON. New York: D Appleton and Cia, no date.

RUIZ PATINO, Jorge Humberto. La política del sport: Elites y deporte en la construcción de la nación colombiana, 1903-1925. Bogotá: La Carreta Editores, 2010.

SANTA CRUZ, Eduardo. Origen y futuro de una pasión: futbol, cultura y modernidad. Santiago: LOM, 1996.

SIEVEKING, J.D. Foot Ball. Reglas del juego fijadas por la Asociación de Gran Bretaña. Santiago: Hume y Cia Libreria Inglesa, 1901.

WEBER, Ernest. Sports athleticos. Rio de Janeiro: H. Garnier, 1907. 